\title{
Simulation of Liquid Flow in Pipe
}

Blanka Skočilasová1, Jan Skočilas ${ }^{2}$

${ }^{1}$ Jan Evangelista Purkyně University in Ústí nad Labem, Faculty of Production Technology and Management, Na Okraji 1001, 40096 Ústí nad Labem, Czech Republic. e-mail: skocilasova@ @vtm.ujep.cz

${ }^{2}$ Czech Technical University in Prague, Faculty of Mechanical Engineering, Technická 4, 16607 Praha 6, Czech Republic. e-mail: jan.skocilas@fs.cvut.cz

The paper deals with the mathematic modeling of the liquid turbulent flow in the pipe with circular cross-section. The aim is to compare two methods of solution for various geometries and Reynolds numbers. One of the methods is simulation of the system in the commercial software ANSYS Fluent, the second one is analytical solution for simple geometry by equation usually applied in the common design process. The work arises from the requirement to design the computational model based on the FVM, which enables to simulate the various physical phenomena which appear at liquid flow. The solved problem is quite range and therefore the work is only the first part of the systematic investigation. This basic part is important for the decision of the suitable software tools, turbulent model, etc. The investigation of the heat transfer on the cross flow over the tube placed in the bounded surrounding.

Keywords: fluid flow, turbulence, Reynolds number, circular tube

\section{Acknowledgement}

The work presented in this paper was supported by SGA grant UJEP Ústí nad Labem, 2010-2012.

\section{References}

[1] BEJAN, A., KRAUS, A., D.: Heat transfer Handbook, John Wiley and sons, Inc., Hoboken, New Jersey, 2003, ISBN 0-471-39015-1

[2] DIPANKAR, CH., SAKIR, A.: Two-dimensional mixed convection heat transfer from confined tandem square cylinders in Gross-flow at low Reynolds numbers. International Communications in Heat and Mass Transfer 37 , (2010), p. 7-16

[3] GRZINCIC, M., DJURDJEVIC, M., DIRNBERGER, F.: Using of Thermal Analysis in the Industrial PracticleConsumption Reduction of Grain-Refinement Master Alloy and Optimization of Computer Simulation Results. Manufacturing Technology, vol. 13, no. 1, p. 39-43, ISSN 1213-2489

[4] HUANG C. K., CHENG Y. J., KANG Y. P.: Combined effect of grid turbulence and unsteady wake on convective heat transfer around a heated cylinder, International Communications in Heat and Mass Transfer 34 (2007), p. 1091-1100.

[5] KEREKEŠOVÁ, K., ČUBOŇOVÁ, M., MICHALKO, M.: Využití genetických algoritmů při řešení optimalizace úloh ve strojírenství, Strojírenská technologie 2007, vol. 1, p. 7-9, ISSN 1211-4162

[6] KIEFT R. N., RINDT C. C. M., VAN STEENHOVEN A., VAN HEIJST G. J. F.: On the wake structure behind a heated horizontal cylinder in cross-flow. J Fluid Mech 2003;486:189.

[7] KOVANDA, K., HOLUB, L., KOLAŘÍK, L., KOLAŘÍKOVÁ, M., VONDROUŠ P.: Experimental Verification of FEM Simulation of GMAV Bead on Plate Welding. Manufacturing technology, vol. 12, no. 12, p. 30-33, ISSN 1213-2489

[8] NOSKIEVIČ, P.: Modelování a identifikace systémů, Montanex a. s. Ostrava, 1999, ISBN 80-7225-030-2.

[9] PLETCHER, R., H. ET al.: Computational fluid mechanics and heat transfer, CRC Press, Taylor and Francis, 2013, ISBN 978-1-159-169303-75

[10] SEUNTIENS, H., KIEFT, R., RINDT, C., VAN STEENHOVEN, A.: 2D temperature measurements in the wake of a heated cylinder using LIF. Exp. Fluids 31, 2001, p. 588-595

[11] WANG, A., TRÁVNÍČEK, Z., CHIA, K., On the relationship of effective Reynolds number and Strouhal number for the laminar vortex shedding of a heated circular cylinder. Phys. Fluids 12, 2000. p 1401-1410.

[12] ŽUKAUSKAS, A., ŠLANČIAUSKAS, A.: Теплоотдача в турбулентном пототоке жидкости (Sdílení tepla v turbulentním proudu tekutiny), Vyd. Mintis, Vijnius, Litva, 1973 